medRxiv preprint doi: https://doi.org/10.1101/2021.02.01.21250963; this version posted February 3, 2021. The copyright holder for this preprint (which was not certified by peer review) is the author/funder, who has granted medRxiv a license to display the preprint in perpetuity.

\title{
Risk factors for SARS-CoV-2 infection among farmworkers in Monterey County, California
}

Ana M. Mora, ${ }^{1,2, *, \dagger}$ Joseph A. Lewnard, ${ }^{3,4,5, \star}$ Katherine Kogut, ${ }^{1}$ Stephen A. Rauch, ${ }^{1}$ Norma Morga, ${ }^{6}$ Samantha Hernandez, ${ }^{5}$ Marcus P. Wong, ${ }^{5}$ Karen Huen, ${ }^{1}$ Cynthia Chang, ${ }^{1}$ Nicholas P. Jewell, ${ }^{7,8}$ Nina Holland, ${ }^{1}$ Eva Harris, ${ }^{5}$ Maximiliano Cuevas, ${ }^{6}$ Brenda Eskenazi ${ }^{1,4}$ on behalf of the CHAMACOS-Project-19 Study Team

1. Center for Environmental Research and Children's Health, School of Public Health, University of California, Berkeley, Berkeley, California

2. Central American Institute for Studies on Toxic Substances, Universidad Nacional, Heredia, Costa Rica

3. Center for Computational Biology, College of Engineering, University of California, Berkeley, Berkeley, California

4. Division of Epidemiology, School of Public Health, University of California, Berkeley, Berkeley, California

5. Division of Infectious Diseases \& Vaccinology, School of Public Health, University of California, Berkeley, Berkeley, California

6. Clinica de Salud del Valle de Salinas, Salinas, California

7. Department of Medical Statistics, London School of Hygiene and Tropical Medicine, London, United Kingdom

8. Division of Biostatistics, School of Public Health, University of California, Berkeley, Berkeley, California

* These authors contributed equally to the work.

${ }^{\dagger}$ Address for correspondence:

Ana M. Mora, MD PhD

1995 University Avenue suite 265

Berkeley, California 94720

(510) 295-9575

animora@berkeley.edu

Manuscript word count: 2979 words 
medRxiv preprint doi: https://doi.org/10.1101/2021.02.01.21250963; this version posted February 3, 2021. The copyright holder for this preprint (which was not certified by peer review) is the author/funder, who has granted medRxiv a license to display the preprint in perpetuity.

All rights reserved. No reuse allowed without permission.

\section{ABSTRACT}

Importance: Essential workers in agriculture and food production have been severely affected by the ongoing COVID-19 pandemic.

Objective: To identify risk factors associated with SARS-CoV-2 shedding and antibody response in farmworkers in California.

Design: This cross-sectional study collected survey data and determined current SARS-CoV-2 shedding and seropositivity among 1,107 farmworkers in California's Salinas Valley from 16 July to 30 November 2020.

Setting: Farmworkers receiving transcription-mediated amplification (TMA) tests for SARS-CoV-2 infection at federally qualified community clinics and community sites were invited to participate in our study.

Participants: Individuals were eligible if they were not pregnant, $\geq 18$ years old, had conducted farm work since the pandemic started, and were proficient in English or Spanish.

Exposures: Sociodemographic, household, community, and workplace characteristics.

Main Outcome(s) and Measure(s): Current (as indicated by TMA positivity) and historical (as indicated by IgG seropositivity) SARS-CoV-2 infection.

Results: Most farmworkers enrolled in the study were born in Mexico, had primary school or lower levels of educational attainment, and were overweight or obese. Current SARS-CoV-2 shedding was associated in multivariable analyses with attained only primary or lower educational levels ( $\mathrm{RR}=1.32 ; 95 \% \mathrm{Cl}$ : 0.991.76), speaking an indigenous language at home $(R R=1.30 ; 0.97-1.73)$, working in the fields $(R R=1.60$; 1.03-2.50), and exposure to known or suspected COVID-19 case at home ( $R R=2.98 ; 2.06-4.32)$ or in the workplace ( $R R=1.59 ; 1.18-2.14)$. Antibody detection was associated with residential exposures including living in crowded housing $(R R=1.23 ; 0.98-1.53)$, with children $(R R=1.40 ; 1.1-1.76)$ or unrelated roommates ( $R R=1.40 ; 1.19-1.64)$, and with a known or suspected COVID-19 case (RR=1.59; 1.13-2.24). Those who were obese $(R R=1.65 ; 1.01-2.70)$ or diabetic $(R R=1.31 ; 0.98-1.75)$ were also more likely to be seropositive. Farmworkers who lived in rural areas other than Greenfield ( $R R=0.58 ; 0.47-0.71)$, worked indoors ( $R R=0.68 ; 0.61-0.77)$, or whose employer provided them with information on how to protect themselves at work $(\mathrm{RR}=0.59 ; 0.40-0.86)$ had lower risk of prior infection. 
medRxiv preprint doi: https://doi.org/10.1101/2021.02.01.21250963; this version posted February 3, 2021. The copyright holder for this preprint (which was not certified by peer review) is the author/funder, who has granted medRxiv a license to display the preprint in perpetuity. All rights reserved. No reuse allowed without permission.

Conclusions and Relevance: Our findings suggest both residential and workplace exposures are contributing to SARS-CoV-2 infection among farmworkers in California. Urgent distribution of COVID-19 vaccines is warranted given this population's increased risk of infection and the essential nature of their work. 
medRxiv preprint doi: https://doi.org/10.1101/2021.02.01.21250963; this version posted February 3, 2021. The copyright holder for this preprint (which was not certified by peer review) is the author/funder, who has granted medRxiv a license to display the preprint in perpetuity.

All rights reserved. No reuse allowed without permission.

\section{INTRODUCTION}

Essential workers in agriculture and food production have been severely affected by the ongoing COVID19 pandemic. Widely-reported outbreaks associated with occupational exposure to SARS-CoV-2 have strained U.S. food supply chains ${ }^{1}$ and drawn attention to circumstances potentially placing workers at risk, including poor hygienic conditions, lack of access to educational materials in languages other than English, medical leave policies, and residential crowding. ${ }^{2}$

Agricultural work is one of the lowest-paid occupations of the U.S. economy, with $29 \%$ of full-time workers earning an annual income below $\$ 26,200$ for a family of four. ${ }^{3}$ More than half of U.S. farmworkers are Latino, ${ }^{4}$ and many live in crowded housing of substandard quality. ${ }^{5}$ In California, at least half of farmworkers are believed to be undocumented, which could further lead to labor exploitation and a less protected working environment. ${ }^{6}$ In a study in Monterey County, California, we have reported 4-fold higher SARS-CoV-2 test positivity among farmworkers than the county population at large, and $24 \%$ higher test positivity among farmworkers than other individuals residing in the same communities. ${ }^{7}$ Statewide, agricultural and food workers experienced a 39\% higher risk of all-cause death from March-October 2020 than during the same period in 2019 - a greater increase than any other occupational group; ${ }^{8}$ for workers of Latino backgrounds, the increase in all-cause mortality was $60 \%{ }^{9}$

Because specific exposures accounting for the high risk of infection among farmworkers remain poorly understood, there is uncertainty about what strategies can reduce risk of infection in this population. ${ }^{10}$ Here, we assessed sociodemographic, household, community, and workplace factors associated with SARS-CoV-2 infection and antibody response in a population of over 1,000 farmworkers working in the Salinas Valley in Monterey County, California.

\section{METHODS}

\section{Study setting}

The Salinas Valley, located within Monterey County, California, is home to an agricultural workforce of approximately 50,000 resident farmworkers, with an additional 40,000 seasonal workers supporting the peak summer and fall seasons. ${ }^{11}$ Clinica de Salud del Valle de Salinas (CSVS), a federally qualified community health center, is the main healthcare provider for Monterey County's farmworkers and their families with a network of 12 clinics throughout the valley serving approximately 50,000 low-income, primarily Spanish-speaking patients. 
medRxiv preprint doi: https://doi.org/10.1101/2021.02.01.21250963; this version posted February 3, 2021. The copyright holder for this preprint (which was not certified by peer review) is the author/funder, who has granted medRxiv a license to display the preprint in perpetuity.

All rights reserved. No reuse allowed without permission.

\section{SARS-CoV-2 testing}

Testing for SARS-CoV-2 infection at CSVS began 15 June 2020 and was offered to all individuals regardless of exposure, symptoms, documentation, or health insurance status. Medical personnel collected oropharyngeal specimens for detection of SARS-CoV-2 RNA via the qualitative Hologic (Marlborough, Massachusetts) Aptima nucleic acid transcription-mediated amplification (TMA) assay. Testing was conducted on clinic premises or at community sites, including low-income housing, agricultural fields, and CSVS-run community health fairs.

\section{Study enrollment}

Between 16 July and 30 November 2020, we invited farmworkers (i.e., anyone employed in the agricultural sector) receiving care or getting tested for SARS-CoV-2 infection at CSVS clinics and community sites to participate in our study. We posted flyers about the study at the clinics and around town and provided study information to community groups and growers. Farmworkers were eligible for participation if they were not pregnant, $\geq 18$ years old, had conducted farm work within the two weeks preceding their testing date, and were sufficiently proficient in English or Spanish to give consent and complete study procedures. Beginning 5 October, we enrolled any individuals who had engaged in agricultural work at any time since March 2020 since the growing season was ending.

We enrolled a total of 1,115 farmworkers. We excluded 8 farmworkers who did not provide blood samples or were not employed as farmworkers at time of enrollment from analyses, leaving a total of 1,107 participants. Study protocols were approved by the Office for the Protection of Human Subjects at UC Berkeley. All participants provided informed written consent.

\section{Study procedures}

After the participant completed the SARS-CoV-2 TMA test and consented to participate in the study, the study team obtained a blood sample by venipuncture for testing of anti-SARS-CoV-2 antibody status. We then measured (with shoes on) height and weight using a digital scale. The study team administered a 45-minute computer-guided questionnaire by telephone in Spanish or English within two days before (for pre-consented participants) or after the enrollment visit, but before SARS-CoV-2 testing results were available. The questionnaire gathered information on socio-demographic characteristics, risk factors for SARS-CoV-2 infection, and impacts of the pandemic on daily life and wellbeing. Participants received a $\$ 50$ prepaid VISA gift card which was loaded upon completion of all data collection activities. 
medRxiv preprint doi: https://doi.org/10.1101/2021.02.01.21250963; this version posted February 3, 2021. The copyright holder for this preprint (which was not certified by peer review) is the author/funder, who has granted medRxiv a license to display the preprint in perpetuity.

All rights reserved. No reuse allowed without permission.

Blood specimens were stored immediately at $4-7^{\circ} \mathrm{C}$ and centrifuged and aliquoted within 48 hours following collection. We used an in-house enzyme-linked immunosorbent assay (ELISA) to measure immunoglobulin $\mathrm{G}(\mathrm{IgG})$ reactivity to the SARS-CoV-2 spike and receptor binding domain proteins, as described previously. ${ }^{7}$ Prior validation of the assay used convalescent sera from hospitalized, mildly symptomatic, and asymptomatic PCR-positive cases as well as pre-2020 control specimens.

\section{Statistical analyses}

We analyzed current (TMA-positivity) and historical (IgG antibody reactivity) SARS-CoV-2 infection separately. Analyses examining risk factors for TMA positivity included participants who worked in agriculture in the two weeks preceding enrollment $(n=911)$; analyses for seropositivity included all farmworkers who provided a blood sample $(n=1,058)$.

We performed bivariate analyses for a wide range of socio-demographic, household, community, and work-related characteristics known or suspected to be associated with SARS-CoV-2 infection (Tables 1-4 and eTables 1-4) and assessed correlations between these characteristics (eFigure 1). We included covariates in multivariate models if there were $>5$ TMA positive or seropositive cases in each category, respectively, and a chi-square or t-test $p$-value $<0.2$ in bivariate analyses. Categorical risk factors were modeled as shown in Tables 1-4, with the exception of language spoken at home (modeled as indigenous language spoken at home - yes/no) and working in the fields (yes/no). Age, years in the U.S., and household size were modeled as continuous variables. We did not consider specific agricultural crops in multivariate analyses because farmworkers reported working in a variety of them. We used backward stepwise elimination (with a threshold of $p<0.1$ ) to select covariates for inclusion in final models.

We used multiple imputation with chained equations to account for missing values $(<2.5 \%$ missing for all variables). To account for differences between those recruited at clinics vs. community events, as well as changes in the background positivity rate in Monterey County over the course of the study period, we grouped participants into strata by recruitment site and period (i.e., 16 July-31 August, 1-30 September, 1-31 October, or 1-30 November). We used conditional fixed-effects Poisson models ${ }^{12}$ to estimate adjusted risk ratios (aRRs) while accounting for differences among strata, estimating robust standard errors using the Huber-White estimator.

\section{RESULTS}

Most study participants were born in Mexico, had primary school or lower levels of educational attainment, were married or living as married, and were overweight or obese (Table 1). Participants 
medRxiv preprint doi: https://doi.org/10.1101/2021.02.01.21250963; this version posted February 3, 2021. The copyright holder for this preprint (which was not certified by peer review) is the author/funder, who has granted medRxiv a license to display the preprint in perpetuity.

All rights reserved. No reuse allowed without permission.

averaged 39.7 (standard deviation $(S D)=12.6$ ) years of age and had lived in the U.S. for an average of $21.3(S D=11.1)$ years. About $85 \%$ spoke Spanish at home, and $10 \%$ spoke an indigenous language. Half of participants reported household earnings $<\$ 25,000$ per year. Three-quarters lived with children, including $36.9 \%$ living with children five years old or younger (Table 2). As many as $18.6 \%$ lived with unrelated roommates and $74.4 \%$ lived with other farmworkers. On average, farmworkers lived with 5.5 $(S D=2.5)$ household members and $36.5 \%$ lived in crowded conditions ( $>2$ persons/bedroom). Few reported leaving home for non-essential reasons (13\%) or attending social gatherings with non-household members $(10.1 \%)$ in the two weeks preceding the survey. As many as $17.9 \%$ reported living with someone who had symptoms of COVID-19 or were known to be infected with SARS-CoV-2 since the pandemic started, and $10.9 \%$ reported such exposures at home in the two weeks preceding their test.

About three-quarters of participants worked in the fields and farmed a variety of crops; the most common were berries (28.6\%), leafy greens (26.4\%), and broccoli (18.8\%) (Table 3). Nearly all farmworkers reported using a face covering at work, and $34.3 \%$ commuted to work with members of other households. Almost $40 \%$ worked during the pandemic with someone who had symptoms of COVID-19 or were known to be infected with SARS-CoV-2 and $13.5 \%$ reported such workplace exposure during the two weeks preceding their testing date. Almost all farmworkers reported that their employers provided them with hand sanitizer, gloves, face coverings, and handwashing stations; disinfected surfaces and tools regularly; and provided them with information on how to prevent SARS-CoV-2 transmission at work and the importance of staying away from work if they were sick (Table 4). However, 44.7\% reported that their employer did not screen for fever and symptoms upon arrival at the workplace, which was recommended as part of a countywide agricultural advisory. ${ }^{13}$

\section{Risk factors for current SARS-CoV-2 infection (TMA-positivity)}

Thirteen percent $(n=118)$ of the 911 participants currently working in agriculture tested positive for current SARS-CoV-2 shedding by TMA, including $18.5 \%$ of those recruited at the clinics and $5.8 \%$ of those recruited via outreach (Table 1). Several socio-demographic, household, community, and work-related variables were associated with TMA positivity in bivariate analyses (Tables 1-4). Notably, we found that participants who had a lower educational level, spoke indigenous languages at home, lived in the community of Greenfield, worked in the fields, did not work indoors, commuted to work with nonhousehold members, lived or worked with someone who had symptoms of COVID-19 or with known infection in the preceding two weeks, and were not screened for either fever or COVID-19 symptoms upon arrival at work had a higher prevalence of TMA positivity. We also observed correlations between some of these characteristics (eFigure 1). 
medRxiv preprint doi: https://doi.org/10.1101/2021.02.01.21250963; this version posted February 3, 2021. The copyright holder for this preprint (which was not certified by peer review) is the author/funder, who has granted medRxiv a license to display the preprint in perpetuity.

All rights reserved. No reuse allowed without permission.

In multivariate analyses, we found that TMA positivity was more common among individuals who had only primary school or no education (aRR=1.32; $95 \% \mathrm{Cl}: 0.99-1.76)$, spoke an indigenous language at home ( $a R R=1.30 ; 0.97-1.73)$, or lived with $(a R R=2.98 ; 2.06-4.32)$ or worked with (aRR=1.59; 1.18-2.14) someone who had symptoms of COVID-19 or was known to be infected with SARS-CoV-2 in the previous two weeks. Additionally, working in the fields (compared to agricultural work in all other settings) was associated with higher risk of current SARS-CoV-2 infection (aRR=1.60; 1.03-2.50). In contrast, farmworkers screened by employers for symptoms of COVID-19 or elevated temperature had a reduced risk of current infection (aRR=0.79; 0.61-1.01; Figure 1A).

\section{Risk factors for prior SARS-CoV-2 infection (IgG antibody reactivity)}

We found that $19 \%$ of the participants who provided a blood sample had antibody evidence of prior infection, with similar prevalence among those tested in the clinics (18.4\%) and at community sites (19.4\%; Table 1). Farmworkers with primary school or no education, who lived in Salinas or Greenfield (vs. other towns), were overweight or obese, lived in large households or with children $\leq 5$ years, lived in crowded housing, had ever lived with someone who had symptoms of COVID-19 or were known to be infected with SARS-CoV-2, and worked in the fields had higher antibody prevalence than their counterparts (Tables 1-3). We also found that those who worked indoors and whose employer provided information on how to protect themselves at work had lower likelihood of seropositivity (Tables $\mathbf{3}$ and $\mathbf{4}$ ).

In multivariate analyses, we found that participants who were obese $(\mathrm{aRR}=1.65 ; 1.01-2.70)$ or overweight $(\mathrm{aRR}=1.42 ; 0.94-2.16)$ or reported being diabetic (aRR=1.31; 0.98-1.75) were more likely to be seropositive. Additionally, we identified higher risk of seropositive status among those living with children $\leq 5$ years old ( $a R R=1.40 ; 1.1-1.76)$, with unrelated roommates ( $a R R=1.40 ; 1.19-1.64)$ or in crowded housing ( $\mathrm{aRR}=1.23 ; 0.98-1.53)$, and those who had ever lived with someone who had symptoms of COVID-19 or were known to be infected with SARS-CoV-2 (aRR=1.59; 1.13-2.24; Figure 1B). Farmworkers who lived outside the region's largest communities of Salinas and Greenfield (aRR $=0.58$; 0.47-0.71), worked indoors ( $\mathrm{aRR}=0.68 ; 0.61-0.77$ ), or whose employer provided them with information on how to protect themselves at work $(\mathrm{aRR}=0.59 ; 0.40-0.86)$ had a decreased risk of serpositivity.

\section{DISCUSSION}

In this primarily Mexican-born and very low-income farmworker population in California, current SARSCoV-2 infection was associated with having lower levels of education, speaking an indigenous language, working in the fields rather than elsewhere in agriculture, and exposure to known or suspected COVID-19 case at home or in the workplace. We also found higher prevalence of prior SARS-CoV-2 infection, 
medRxiv preprint doi: https://doi.org/10.1101/2021.02.01.21250963; this version posted February 3, 2021. The copyright holder for this preprint (which was not certified by peer review) is the author/funder, who has granted medRxiv a license to display the preprint in perpetuity.

All rights reserved. No reuse allowed without permission.

indicated by $\lg$ G seropositivity, associated with outdoor work and with residential exposures (living in crowded housing, with children or unrelated roommates, and with a known or suspected COVID-19 case). Those living in the more urban areas of the county were particularly at risk, as were those who were obese or diabetic. As evidence of the importance of health education, farmworkers who reported that their employer provided them with information on COVID-19 protection were less likely to have been infected.

Our study suggests several routes of SARS-CoV-2 exposure that may be of importance to the farmworker population. Unsurprisingly, living in crowded housing or with unrelated roommates was associated with higher risk of prior infection. Independent of these associations, we also saw higher seroprevalence among individuals living with children five years old or younger. While the role of children in SARS-CoV-2 transmission has been uncertain in many populations, in part due to lower risk of symptoms and lower frequency of testing at younger ages, ${ }^{14-16}$ recent investigations have demonstrated equivalent viral load across ages ${ }^{17}$ and higher risk of transmission from infected children than from adults, given similar household exposures. ${ }^{18}$ While schools and formal daycare establishments were closed during our study, informal or home-based childcare arrangements with relatives or friends may have led to additional exposure to infection. Taken together, our findings suggest substantial risk of infection associated with residential exposures in this low-income essential workforce population.

Several workplace factors were also associated with infection risk. Farmworkers whose employers provided informational resources on preventing COVID-19 at work had $41 \%$ lower risk of prior infection, whereas farmworkers whose employers screened them for symptoms or fever had $21 \%$ lower risk of current infection. This reduction could owe to benefits of health education, as well as more stringent efforts by employers to reduce risk by providing education and screenings. Individuals working outside and in the fields were more likely to be both currently infected and seropositive, respectively. Whereas indoor exposures are thought to be associated with the greatest risk of transmission, ${ }^{19}$ a lower perceived sense of risk during outdoor work, difficulty using PPE while engaged in physically demanding tasks, or socioeconomic differences among outdoor and indoor workers may contribute to the observed association in our study. While the estimated risk ratio for infection associated with workplace exposure was lower than that for household exposure, this difference could in part reflect misclassification, if individuals are are more likely to know about the health of household members. Previously, we have reported higher SARS-CoV-2 test positivity among farmworkers than among age- and sex-matched adults from the same communities who also received testing at CSVS, ${ }^{7}$ further supporting the hypothesis that workplace exposures specific to agriculture may be of importance to SARS-CoV-2 transmission.

Last, we observed that farmworkers who spoke indigenous languages and those with lower education were more likely to currently have COVID-19 at the time of testing. Those who spoke indigenous languages also had a lower educational level and had more recently arrived in the U.S. They lived in 
medRxiv preprint doi: https://doi.org/10.1101/2021.02.01.21250963; this version posted February 3, 2021. The copyright holder for this preprint (which was not certified by peer review) is the author/funder, who has granted medRxiv a license to display the preprint in perpetuity.

All rights reserved. No reuse allowed without permission.

more crowded conditions and were more likely to work in the fields and to commute to work with nonhousehold members (see eFigure 1). Only limited COVID-19 health messages have been provided in indigenous languages, which are primarily not written languages.

We also saw associations of prior infection with comorbid conditions. While it is known that obesity increases the risk for severe COVID-19 illness, ${ }^{20}$ we also observed an increased risk of prior infection among obese individuals. This finding is consistent with a recent meta-analysis of 20 studies which found $46 \%$ higher odds of SARS-CoV-2 infection among obese individuals, ${ }^{20}$ possibly related to alterations in systemic metabolism, including altered adipokines ${ }^{21-23}$ and chronic low-grade inflammation. ${ }^{24,25}$ Similarly, diabetes can attenuate the synthesis of proinflammatory cytokines (e.g., interferon gamma and interleukins) and their downstream acute phase reactants, ${ }^{26}$ but also impair macrophage and lymphocyte functions. ${ }^{27}$ As obesity and diabetes are prevalent among farmworkers as well as other low-income Latino populations, our findings that these conditions are associated with higher risk of infection add to previous concerns based on the knowledge that these conditions may also exacerbate risk of adverse clinical outcomes.

Our work represents the first epidemiological study to address risk factors for SARS-CoV-2 infection among U.S. farmworkers, and substantiates earlier concerns ${ }^{6,28-30}$ that living and working conditions in this population may contribute to risk of infection. Several limitations should be considered. We cannot determine how well our sample represents the farmworker population, many of whom are "hidden" due to their informal workforce participation and undocumented status. ${ }^{31}$ As we excluded individuals who did not speak Spanish or English sufficiently well to participate, our study likely under-represents indigenous populations. We observed differences in prevalence of current, but not prior, SARS-CoV-2 infection between study participants recruited at clinics and those recruited via community outreach events, ${ }^{7}$ as individuals seeking testing at clinics were more likely to be symptomatic or to report recent known exposure; to mitigate confounding, we defined strata by recruitment site. In addition, waning antibodies, particularly for individuals experiencing mild or asymptomatic infection, ${ }^{32}$ may have contributed to misclassification for individuals infected early in the pandemic. Lastly, many identified risk factors were highly correlated, making it difficult to separate out their unique effects.

Our previous analyses demonstrated a high prevalence of SARS-CoV-2 infection among farmworkers in California's Salinas Valley; findings reported here further underscore the urgent need to intervene on modifiable risk factors such as increasing availability of isolation facilities to reduce exposure to COVID19 cases at home and access to paid medical leave to avoid transmission in the workplace. Farmworkers speaking indigenous languages, who have very low levels of formal education, and who live in rural communities were at especially high risk of infection in our study, demonstrate disparities even within this very low-income and high-risk population. Efficacious vaccines have now been authorized and should be 
medRxiv preprint doi: https://doi.org/10.1101/2021.02.01.21250963; this version posted February 3, 2021. The copyright holder for this preprint (which was not certified by peer review) is the author/funder, who has granted medRxiv a license to display the preprint in perpetuity.

All rights reserved. No reuse allowed without permission.

distributed to farmworkers with urgency owing to the high risk of infection in this population, and the essential nature of their work.

\section{ACKNOWLEDGEMENTS}

This work was supported by the Innovative Genomics Institute and Clinica de Salud del Valle de Salinas. JAL discloses receipt of grants and fees from Pfizer unrelated to this study. All other authors declare no conflicts of interest.

The study was reviewed and approved by the Committee for Protection of Human Subjects at UC Berkeley.

Members of the CHAMACOS-Project-19 Study Team include Jose Camacho, Gardenia Casillas, Celeste Castro, Madison J. de Vere, Lupe Flores, Lizari Garcia, Maria Reina Garcia, Terry Gomez, Carly Hyland, Daniel Lampert, Aaron McDowell-Sanchez, Dominic Pina Montes, Jacqueline Montoya, Oguchi Nkwocha, Lilibeth Nunez, Juanita "Liz" Orozco, Marbel Orozco, Kimberly L. Parra, Nargis Rezai, Maria T. Rodriquez, Monica Romero, Hina Sheth, Jon Yoshiyama, and Litzi Zepeda. 
medRxiv preprint doi: https://doi.org/10.1101/2021.02.01.21250963; this version posted February 3, 2021. The copyright holder for this preprint (which was not certified by peer review) is the author/funder, who has granted medRxiv a license to display the preprint in perpetuity.

All rights reserved. No reuse allowed without permission.

\section{REFERENCES}

1. Reiley L, Reinhard B. Virus's unseen hot zone: The American farm. Washington Post. https://www.washingtonpost.com/business/2020/09/24/seasonal-farm-workers-coronavirus/. Accessed January 25, 2021.

2. Dyal JW. COVID-19 among workers in meat and poultry processing facilities-19 states, April 2020. MMWR Morb Mortal Wkly Rep. 2020;69.

3. Stephenson J. COVID-19 Outbreaks Among Food Production Workers May Intensify Pandemic's Disproportionate Effects on People of Color. JAMA Health Forum. 2020;1(6):e200783-e200783. doi:10.1001/jamahealthforum.2020.0783

4. US Department of Agriculture Economic Research Service. Farm Labor. Accessed January 25, 2021. https://www.ers.usda.gov/topics/farm-economy/farm-labor/\#size

5. Bradman A, Chevrier J, Tager I, et al. Association of housing disrepair indicators with cockroach and rodent infestations in a cohort of pregnant Latina women and their children. Environ Health Perspect. 2005;113(12):1795-1801. doi:10.1289/ehp.7588

6. Handal AJ, Iglesias-Ríos L, Fleming PJ, Valentín-Cortés MA, O’Neill MS. "Essential” but Expendable: Farmworkers During the COVID-19 Pandemic-The Michigan Farmworker Project. Am J Public Health. 2020;110(12):1760-1762. doi:10.2105/AJPH.2020.305947

7. Lewnard JA, Mora AM, Nkwocha O, et al. Prevalence and clinical profile of SARS-CoV-2 infection among farmworkers in Monterey County, California: June-November, 2020. medRxiv. Published online January 1, 2021:2020.12.27.20248894. doi:10.1101/2020.12.27.20248894

8. Chen Y-H, Glymour M, Riley A, et al. Excess mortality associated with the COVID-19 pandemic among Californians 18-65 years of age, by occupational sector and occupation: March through October 2020. medRxiv. Published online January 1, 2021:2021.01.21.21250266. doi:10.1101/2021.01.21.21250266

9. Riley AR, Chen Y-H, Matthay EC, et al. Excess deaths among Latino people in California during the COVID-19 pandemic. medRxiv. Published online January 1, 2021:2020.12.18.20248434. doi:10.1101/2020.12.18.20248434

10. Preliminary Data Brief. COVID-19 Farmworkers Study; 2020.

http://covid19farmworkerstudy.org/survey/wp-content/uploads/2020/08/EN-COFS-Preliminary-DataBrief_FINAL.pdf

11. California Institute for Rural Studies. Farmworker Housing Study and Action Plan for Salinas Valley and Pajaro Valley. California Institute for Rural Studies; 2018:502.

https://www.co.monterey.ca.us/home/showdocument?id=63729

12. Armstrong BG, Gasparrini A, Tobias A. Conditional Poisson models: a flexible alternative to conditional logistic case cross-over analysis. BMC Med Res Methodol. 2014;14(1):122. doi:10.1186/1471-2288-14-122 
medRxiv preprint doi: https://doi.org/10.1101/2021.02.01.21250963; this version posted February 3, 2021. The copyright holder for this preprint (which was not certified by peer review) is the author/funder, who has granted medRxiv a license to display the preprint in perpetuity.

All rights reserved. No reuse allowed without permission.

13. Advisory For Agricultural Worker Protection During Covid-19 Crisis On The Central Coast Of California.; 2020. https://www.co.monterey.ca.us/home/showdocument?id=88499

14. Kim L, Whitaker M, O'Halloran A, et al. Hospitalization Rates and Characteristics of Children Aged $<18$ Years Hospitalized with Laboratory-Confirmed COVID-19 - COVID-NET, 14 States, March 1-July 25, 2020. MMWR Morb Mortal Wkly Rep. 2020;69(32):1081-1088. doi:10.15585/mmwr.mm6932e3

15. Swann OV, Holden KA, Turtle L, et al. Clinical characteristics of children and young people admitted to hospital with covid-19 in United Kingdom: prospective multicentre observational cohort study. BMJ. 2020;370:m3249. doi:10.1136/bmj.m3249

16. Zhen-Dong Y, Gao-Jun Z, Run-Ming J, et al. Clinical and transmission dynamics characteristics of 406 children with coronavirus disease 2019 in China: A review. J Infect. 2020;81(2):e11-e15. doi:10.1016/j.jinf.2020.04.030

17. Jones TC, Mühlemann B, Veith T, et al. An analysis of SARS-CoV-2 viral load by patient age. medRxiv. Published online June 9, 2020:2020.06.08.20125484. doi:10.1101/2020.06.08.20125484

18. Li F, Li Y-Y, Liu M-J, et al. Household transmission of SARS-CoV-2 and risk factors for susceptibility and infectivity in Wuhan: a retrospective observational study. Lancet Infect Dis. Published online 2021.

19. Bulfone TC, Malekinejad M, Rutherford GW, Razani N. Outdoor Transmission of SARS-CoV-2 and Other Respiratory Viruses: A Systematic Review. J Infect Dis. 2020;(jiaa742). doi:10.1093/infdis/jiaa742

20. Popkin BM, Du S, Green WD, et al. Individuals with obesity and COVID-19: A global perspective on the epidemiology and biological relationships. Obes Rev. 2020;21(11):e13128. doi:10.1111/obr.13128

21. Rasouli N, Kern PA. Adipocytokines and the metabolic complications of obesity. J Clin Endocrinol Metab. 2008;93(11 Suppl 1):S64-S73. doi:10.1210/jc.2008-1613

22. Grossmann V, Schmitt VH, Zeller T, et al. Profile of the Immune and Inflammatory Response in Individuals With Prediabetes and Type 2 Diabetes. Diabetes Care. 2015;38(7):1356. doi:10.2337/dc14-3008

23. Wada J, Makino H. Innate immunity in diabetes and diabetic nephropathy. Nat Rev Nephrol. 2016;12(1):13.

24. Maurizi G, Della Guardia L, Maurizi A, Poloni A. Adipocytes properties and crosstalk with immune system in obesity-related inflammation. J Cell Physiol. 2018;233(1):88-97. doi:10.1002/jcp.25855

25. McLaughlin T, Ackerman SE, Shen L, Engleman E. Role of innate and adaptive immunity in obesityassociated metabolic disease. J Clin Invest. 2017;127(1):5-13. doi:10.1172/JCI88876

26. Odegaard JI, Chawla A. Connecting type 1 and type 2 diabetes through innate immunity. Cold Spring Harb Perspect Med. 2012;2(3):a007724.

27. Dooley KE, Chaisson RE. Tuberculosis and diabetes mellitus: convergence of two epidemics. Lancet Infect Dis. 2009;9(12):737-746. 
medRxiv preprint doi: https://doi.org/10.1101/2021.02.01.21250963; this version posted February 3, 2021. The copyright holder for this preprint

(which was not certified by peer review) is the author/funder, who has granted medRxiv a license to display the preprint in perpetuity.

All rights reserved. No reuse allowed without permission.

28. Bojorquez K. CA lawmakers urge relief for farm workers amid pandemic | The Sacramento Bee. Published August 2020. Accessed January 25, 2021. https://www.sacbee.com/news/politicsgovernment/capitol-alert/article244769262.html

29. Lazo A. As California Struggles With Covid-19, Farmworkers Are Among Most Affected - WSJ. Published August 2020. Accessed January 25, 2021. https://www.wsj.com/articles/as-californiastruggles-with-covid-19-farmworkers-are-among-most-affected-11597665116

30. Knight V. Without Federal Protections, Farm Workers Risk Coronavirus Infection To Harvest Crops. NPR.org. Published August 2020. Accessed January 25, 2021. https://www.npr.org/sections/healthshots/2020/08/08/900220260/without-federal-protections-farm-workers-risk-coronavirus-infection-toharvest-c

31. Bail KM, Foster J, Dalmida SG, et al. The impact of invisibility on the health of migrant farmworkers in the southeastern United States: a case study from Georgia. Nurs Res Pract. 2012;2012:760418-

760418. doi:10.1155/2012/760418

32. Choe PG, Kang CK, Suh HJ, et al. Waning Antibody Responses in Asymptomatic and Symptomatic SARS-CoV-2 Infection. Emerg Infect Dis. 2021;27(1):327-329. doi:10.3201/eid2701.203515 


\section{TABLES AND FIGURES}

Table 1. Socio-demographic and health-related risk factors for TMA positivity and seropositivity among farmworkers, Monterey County, 2020.

\begin{tabular}{|c|c|c|c|c|c|}
\hline \multirow[t]{3}{*}{ Attribute } & \multirow[b]{2}{*}{$\begin{array}{l}\text { All enrolled } \\
\quad N=1107\end{array}$} & \multicolumn{2}{|c|}{$\begin{array}{c}\text { Current SARS-CoV-2 } \\
\text { infection (TMA) } \\
N=911\end{array}$} & \multicolumn{2}{|c|}{$\begin{array}{c}\text { Historical SARS-CoV-2 } \\
\text { infection (IgG reactivity) } \\
N=1058\end{array}$} \\
\hline & & $\begin{array}{c}\text { Positive } \\
N=118\end{array}$ & $\begin{array}{c}\text { Negative } \\
N=793\end{array}$ & $\begin{array}{c}\text { Positive } \\
N=201\end{array}$ & $\begin{array}{c}\text { Negative } \\
N=857\end{array}$ \\
\hline & $\begin{array}{l}n(\%) \text { or } \\
\mathrm{M} \pm \mathrm{SD}\end{array}$ & $\begin{array}{l}n(\%) \text { or } \\
M \pm S D\end{array}$ & $\begin{array}{l}n(\%) \text { or } \\
M \pm S D\end{array}$ & $\begin{array}{l}n(\%) \text { or } \\
M \pm S D\end{array}$ & $\begin{array}{l}n(\%) \text { or } \\
M \pm S D\end{array}$ \\
\hline \multicolumn{6}{|l|}{ Recruitment site } \\
\hline Clinics & $561(50.7)$ & $95(18.5)^{*}$ & $420(81.6)$ & $97(18.4)$ & $429(81.6)$ \\
\hline Community outreach & $546(49.3)$ & $23(5.8)$ & $373(94.2)$ & $104(19.6)$ & $428(80.5)$ \\
\hline \multicolumn{6}{|l|}{$\begin{array}{l}\text { Agricultural work in the } \\
\text { preceding two weeks }\end{array}$} \\
\hline No & $193(17.4)$ & $23(11.5)$ & $177(88.5)$ & $156(18.0)^{\dagger}$ & $148(82.0)$ \\
\hline Yes & $914(82.6)$ & $118(13.0)$ & $793(87.1)$ & 45 (23.3) & 709 (76.7) \\
\hline \multicolumn{6}{|l|}{ Sex } \\
\hline Female & $581(52.5)$ & $60(13.0)$ & $400(87.0)$ & $99(18.1)$ & $448(81.9)$ \\
\hline Male & $526(47.5)$ & $58(12.9)$ & $393(87.1)$ & $102(20.0)$ & $409(80.0)$ \\
\hline Age (years) & $39.7 \pm 12.6$ & $39.6 \pm 11.0$ & $39.6 \pm 12.4$ & $39.6 \pm 12.3$ & $39.6 \pm 12.6$ \\
\hline $18-29$ & $275(24.8)$ & $27(12.0)$ & $198(88.0)$ & $43(16.4)^{\#}$ & $220(83.7)$ \\
\hline $30-39$ & $271(24.5)$ & $29(13.0)$ & $195(87.1)$ & $59(22.5)$ & $203(77.5)$ \\
\hline $40-49$ & $297(26.8)$ & $42(16.4)$ & $214(83.6)$ & $59(20.8)$ & $225(79.2)$ \\
\hline $50-59$ & $198(17.9)$ & $16(10.2)$ & 141 (89.8) & $27(14.5)$ & $159(85.5)$ \\
\hline$\geq 60$ & $66(6.0)$ & $4(8.2)$ & $45(91.8)$ & $13(20.6)$ & $50(79.4)$ \\
\hline \multicolumn{6}{|l|}{ Education } \\
\hline Primary school complete or & $488(44.1)$ & $63(15.4)^{*}$ & $346(84.6)$ & $84(21.3)^{*}$ & $311(78.7)$ \\
\hline less & & & & & \\
\hline More than primary school & $618(55.8)$ & $55(11.0)$ & $446(89.0)$ & $72(15.4)$ & $397(84.7)$ \\
\hline No answer & $1(0.1)$ & $0(0.0)$ & $1(100.0)$ & $0(0.0)$ & $1(100.0)$ \\
\hline \multicolumn{6}{|l|}{ Marital status } \\
\hline $\begin{array}{l}\text { Not married or living as } \\
\text { married }\end{array}$ & $697(63.0)$ & $50(15.3)^{\#}$ & $277(84.7)$ & $69(17.8)$ & $319(82.2)$ \\
\hline Married or living as married & $409(37.0)$ & $67(11.5)$ & $516(88.5)$ & $132(19.7)$ & $537(80.3)$ \\
\hline No answer & $1(0.1)$ & $1(100.0)$ & $0(0.0)$ & $0(0.0)$ & $1(100.0)$ \\
\hline \multicolumn{6}{|l|}{ Annual household income } \\
\hline$<\$ 25,000$ & $557(50.3)$ & $66(14.5)$ & $390(85.5)$ & $101(18.8)$ & $435(81.2)$ \\
\hline$\geq \$ 25,000$ & $494(44.6)$ & $48(11.6)$ & $367(88.4)$ & $86(18.5)$ & $380(81.6)$ \\
\hline No answer & $56(5.1)$ & $4(10.0)$ & $36(90.0)$ & $14(25.0)$ & $42(75.0)$ \\
\hline \multicolumn{6}{|l|}{ Language spoken at home } \\
\hline Spanish & $940(84.9)$ & $96(12.4)^{*}$ & $676(87.6)$ & $166(18.5)$ & $730(81.5)$ \\
\hline English & $57(5.2)$ & $0(0.0)$ & $42(100.0)$ & $12(21.8)$ & $43(78.2)$ \\
\hline Indigenous & $110(9.9)$ & $22(22.7)$ & $75(77.3)$ & $23(21.5)$ & $84(78.5)$ \\
\hline No answer & $0(0.0)$ & $0(0.0)$ & $0(0.0)$ & $0(0.0)$ & $0(0.0)$ \\
\hline \multicolumn{6}{|l|}{ Country of birth } \\
\hline Mexico & $922(83.3)$ & $104(13.5)^{\#}$ & $669(86.5)$ & $163(18.4)$ & $721(81.6)$ \\
\hline US & $141(12.7)$ & $7(7.0)$ & $93(93.0)$ & $31(23.0)$ & $104(77.0)$ \\
\hline Other & $44(4.0)$ & $7(18.4)$ & $31(81.6)$ & $7(18.0)$ & $32(82.1)$ \\
\hline Years in US & $21.3 \pm 11.1$ & $20.2 \pm 10.9^{\#}$ & $21.0 \pm 11.2$ & $21.3 \pm 10.6$ & $21.2 \pm 11.3$ \\
\hline$<15$ & $262(23.7)$ & $38(16.5)^{\#}$ & $193(83.6)$ & $46(18.0)^{\#}$ & $209(82.0)$ \\
\hline $15-19$ & $191(17.3)$ & $17(10.4)$ & $147(89.6)$ & $44(24.0)$ & $139(76.0)$ \\
\hline $20-29$ & $296(26.7)$ & $34(13.5)$ & $218(86.5)$ & $49(17.4)$ & $232(82.6)$ \\
\hline$\geq 30$ & $216(19.5)$ & $22(13.4)$ & $142(86.6)$ & $31(15.3)$ & $172(84.7)$ \\
\hline Entire life & $141(12.7)$ & $7(7.0)$ & 93 (93.0) & $31(23.0)$ & $104(77.0)$ \\
\hline
\end{tabular}


medRxiv preprint doi: https://doi.org/10.1101/2021.02.01.21250963; this version posted February 3, 2021. The copyright holder for this preprint (which was not certified by peer review) is the author/funder, who has granted medRxiv a license to display the preprint in perpetuity. All rights reserved. No reuse allowed without permission.

\begin{tabular}{|c|c|c|c|c|c|}
\hline No answer & $1(0.1)$ & $0(0.0)$ & $0(0.0)$ & $0(0.0)$ & $1(100.0)$ \\
\hline \multicolumn{6}{|l|}{ Community of residence } \\
\hline Salinas & $486(43.9)$ & $40(10.4)^{*}$ & $343(89.6)$ & $99(21.2)^{*}$ & 369 (78.9) \\
\hline Greenfield & $315(28.5)$ & $56(19.8)$ & $227(80.2)$ & $63(21.2)$ & $234(78.8)$ \\
\hline Other town & $306(27.6)$ & $22(9.0)$ & $223(91.0)$ & 39 (13.3) & $254(86.7)$ \\
\hline \multicolumn{6}{|l|}{ Smoking } \\
\hline Never smoked & $899(81.2)$ & 99 (13.6) & $630(86.4)$ & $157(18.4)$ & $698(81.6)$ \\
\hline Former smoker & $158(14.3)$ & $16(11.4)$ & $124(88.6)$ & $36(23.4)$ & $118(76.6)$ \\
\hline Current smoker & $49(4.4)$ & $3(7.3)$ & $38(92.7)$ & $8(16.7)$ & $40(83.3)$ \\
\hline No answer & $1(0.1)$ & $0(0.0)$ & $1(100.0)$ & $0(0.0)$ & $1(100.0)$ \\
\hline Body mass index (measured) & $29.7 \pm 5.5$ & $29.2 \pm 4.7$ & $29.7 \pm 5.6$ & $30.4 \pm 5.4^{*}$ & $29.4 \pm 5.5$ \\
\hline$<25$ (underweight or normal) & $197(17.8)$ & $18(10.8)$ & $149(89.2)$ & $24(12.5)^{\star}$ & $168(87.5)$ \\
\hline $25-29.9$ (overweight) & $421(38.0)$ & $45(13.0)$ & $302(87.0)$ & $75(18.6)$ & $329(81.4)$ \\
\hline$\geq 30$ (obese) & $461(41.6)$ & $49(13.1)$ & $326(86.9)$ & $95(21.7)$ & $342(78.3)$ \\
\hline Not collected & $28(2.5)$ & $6(27.3)$ & $16(72.7)$ & $7(28.0)$ & $18(72.0)$ \\
\hline \multicolumn{6}{|l|}{ Self-reported hypertension } \\
\hline No & $954(86.2)$ & $106(13.5)$ & $680(86.5)$ & $171(18.7)$ & $744(81.3)$ \\
\hline Yes & 149 (13.5) & $12(9.8)$ & $110(90.2)$ & $29(20.9)$ & $110(79.1)$ \\
\hline No answer & $4(0.4)$ & $0(0.0)$ & $3(100.0)$ & $1(25.0)$ & $3(75.0)$ \\
\hline \multicolumn{6}{|l|}{ Self-reported diabetes } \\
\hline No & $977(88.3)$ & $109(13.6)^{\#}$ & $694(86.4)$ & $172(18.4)^{\#}$ & $762(81.6)$ \\
\hline Yes & $126(11.4)$ & $9(8.6)$ & $96(91.4)$ & $28(23.3)$ & $92(76.7)$ \\
\hline No answer & $4(0.4)$ & $0(0.0)$ & $3(100.0)$ & $1(25.0)$ & $3(75.0)$ \\
\hline
\end{tabular}


medRxiv preprint doi: https://doi.org/10.1101/2021.02.01.21250963; this version posted February 3, 2021. The copyright holder for this preprint (which was not certified by peer review) is the author/funder, who has granted medRxiv a license to display the preprint in perpetuity.

All rights reserved. No reuse allowed without permission.

Table 2. Household and community risk factors for TMA positivity and seropositivity among farmworkers, Monterey County, 2020.

\begin{tabular}{|c|c|c|c|c|c|}
\hline \multirow[t]{3}{*}{ Attribute } & \multirow[b]{2}{*}{$\begin{array}{c}\text { All enrolled } \\
N=1107\end{array}$} & \multicolumn{2}{|c|}{$\begin{array}{c}\text { Current SARS-CoV-2 } \\
\text { infection (TMA) } \\
N=911\end{array}$} & \multicolumn{2}{|c|}{$\begin{array}{c}\text { Historical SARS-CoV-2 } \\
\text { infection (IgG reactivity) } \\
N=1058\end{array}$} \\
\hline & & $\begin{array}{c}\text { Positive } \\
N=118\end{array}$ & $\begin{array}{c}\text { Negative } \\
N=793\end{array}$ & $\begin{array}{c}\text { Positive } \\
N=201\end{array}$ & $\begin{array}{c}\text { Negative } \\
N=857\end{array}$ \\
\hline & $\begin{array}{l}n(\%) \text { or } \\
M \pm S D\end{array}$ & $\begin{array}{l}n(\%) \text { or } \\
M \pm S D\end{array}$ & $\begin{array}{l}n(\%) \text { or } \\
M \pm S D\end{array}$ & $\begin{array}{l}n(\%) \text { or } \\
M \pm S D\end{array}$ & $\begin{array}{l}n(\%) \text { or } \\
M \pm S D\end{array}$ \\
\hline \multicolumn{6}{|l|}{ Type of housing } \\
\hline House & $522(47.2)$ & $60(13.5)$ & $383(86.5)$ & $101(20.6)$ & $389(79.4)$ \\
\hline Apartment & $481(43.6)$ & $48(12.9)$ & $324(87.1)$ & $85(18.2)$ & $383(81.8)$ \\
\hline Hotel or motel & $37(3.3)$ & $6(16.7)$ & $30(83.3)$ & $5(13.5)$ & $32(86.5)$ \\
\hline Trailer or mobile home & $43(3.9)$ & $3(7.7)$ & $36(92.3)$ & $8(19.5)$ & $33(80.5)$ \\
\hline Other & $24(2.2)$ & $1(4.8)$ & $20(95.2)$ & $2(9.1)$ & $20(90.9)$ \\
\hline Household size & $5.5 \pm 2.5$ & $5.5 \pm 2.4$ & $5.4 \pm 2.3$ & $5.9 \pm 2.6^{*}$ & $5.4 \pm 2.6$ \\
\hline 0 others & $12(1.1)$ & $2(18.2)$ & $9(81.8)$ & $3(25.0)^{*}$ & $9(75.0)$ \\
\hline $1-3$ others & 397 (35.9) & $41(12.4)$ & $290(87.6)$ & $58(15.3)$ & $321(84.7)$ \\
\hline 4- 6 others & $512(46.3)$ & $51(12.3)$ & $363(87.7)$ & $93(19.1)$ & $393(80.9)$ \\
\hline$\geq 7$ others & $186(16.8)$ & $24(15.5)$ & $131(84.5)$ & $47(26.0)$ & $134(74.0)$ \\
\hline Children $<18$ living in the home & $1.8 \pm 1.6$ & $1.8 \pm 1.5$ & $1.8 \pm 1.6$ & $2.1 \pm 1.7^{\star}$ & $1.7 \pm 1.5$ \\
\hline No & $277(25.0)$ & $28(11.9)$ & $207(88.1)$ & $43(16.0)^{\#}$ & $225(84.0)$ \\
\hline Yes & $829(74.9)$ & $90(13.3)$ & $585(86.7)$ & $157(19.9)$ & $632(80.1)$ \\
\hline No answer & $1(0.1)$ & $0(0.0)$ & $1(100.0)$ & $1(100.0)$ & $0(0.0)$ \\
\hline \multicolumn{6}{|l|}{ Children $\leq 5$ living in the home } \\
\hline No & $699(63.1)$ & $79(13.7)$ & $498(86.3)$ & $110(16.4)^{*}$ & $559(83.6)$ \\
\hline Yes & $408(36.9)$ & $39(11.7)$ & $295(88.3)$ & $91(23.4)$ & $298(76.6)$ \\
\hline \multicolumn{6}{|l|}{$\begin{array}{l}\text { Children attending } \\
\text { school/daycare }\end{array}$} \\
\hline No & $1018(92.0)$ & $105(12.6)$ & $726(87.4)$ & $184(18.9)$ & $792(81.2)$ \\
\hline Yes & $85(7.7)$ & $12(15.8)$ & $64(84.2)$ & $16(20.5)$ & $62(79.5)$ \\
\hline No answer & $4(0.4)$ & $1(25.0)$ & $3(75.0)$ & $1(25.0)$ & $3(75.0)$ \\
\hline \multicolumn{6}{|l|}{$\begin{array}{l}\text { Living with unrelated } \\
\text { roommates }\end{array}$} \\
\hline No & $901(81.4)$ & $93(12.7)$ & $639(87.3)$ & $156(18.1)^{\#}$ & $704(81.9)$ \\
\hline Yes & $206(18.6)$ & $25(14.0)$ & $154(86.0)$ & $45(22.7)$ & $153(77.3)$ \\
\hline \multicolumn{6}{|l|}{ Living with other farmworkers } \\
\hline No & $281(25.4)$ & $26(11.6)$ & $198(88.4)$ & $49(18.4)$ & $218(81.7)$ \\
\hline Yes & $823(74.4)$ & $92(13.5)$ & $592(86.6)$ & $151(19.2)$ & $637(80.8)$ \\
\hline No answer & $3(0.3)$ & $0(0.0)$ & $3(100.0)$ & $1(33.3)$ & $2(66.7)$ \\
\hline \multicolumn{6}{|l|}{ Household crowding } \\
\hline$\leq 2$ persons per bedroom & $703(63.5)$ & $71(12.3)$ & $505(87.7)$ & $113(17.0)^{*}$ & $553(83.0)$ \\
\hline$>2$ persons per bedroom & $404(36.5)$ & $47(14.0)$ & $288(86.0)$ & $88(22.5)$ & $304(77.6)$ \\
\hline \multicolumn{6}{|l|}{$\begin{array}{l}\text { Access to washing machine at } \\
\text { home }\end{array}$} \\
\hline No & $411(37.1)$ & $49(14.2)$ & $296(85.8)$ & $77(19.5)$ & $318(80.5)$ \\
\hline Yes & $696(62.9)$ & 69 (12.2) & $497(87.8)$ & $124(18.7)$ & 539 (81.3) \\
\hline \multicolumn{6}{|l|}{$\begin{array}{l}\text { Left home for non-essential } \\
\text { reasons (past } 2 \text { weeks) }\end{array}$} \\
\hline No & $957(86.5)$ & $104(13.1)$ & $693(87.0)$ & 169 (18.5) & $745(81.5)$ \\
\hline Yes & $144(13.0)$ & $12(11.0)$ & $97(89.0)$ & $29(21.0)$ & $109(79.0)$ \\
\hline No answer & $6(0.5)$ & $2(40.0)$ & $3(60.0)$ & $3(50.0)$ & $3(50.0)$ \\
\hline \multicolumn{6}{|l|}{$\begin{array}{l}\text { Used public transportation/ride } \\
\text { share services (past } 2 \text { weeks) }\end{array}$} \\
\hline No & 1039 (93.9) & $113(13.2)^{\#}$ & $745(86.8)$ & $189(19.1)$ & $801(80.9)$ \\
\hline Yes & $62(5.6)$ & $3(6.3)$ & $45(93.8)$ & $8(14.5)$ & $53(85.5)$ \\
\hline
\end{tabular}


medRxiv preprint doi: https://doi.org/10.1101/2021.02.01.21250963; this version posted February 3, 2021. The copyright holder for this preprint (which was not certified by peer review) is the author/funder, who has granted medRxiv a license to display the preprint in perpetuity.

All rights reserved. No reuse allowed without permission.

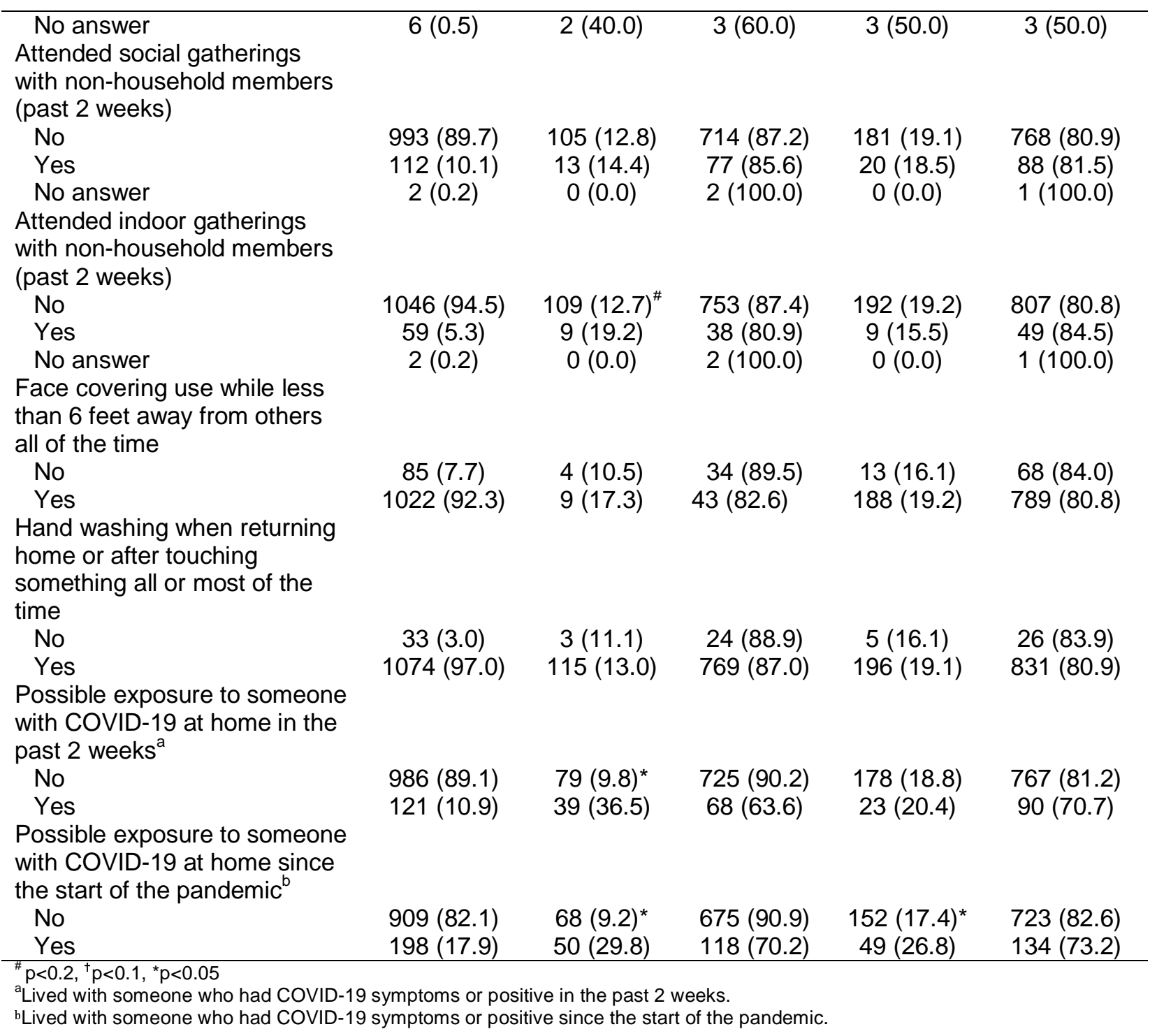


medRxiv preprint doi: https://doi.org/10.1101/2021.02.01.21250963; this version posted February 3, 2021. The copyright holder for this preprint (which was not certified by peer review) is the author/funder, who has granted medRxiv a license to display the preprint in perpetuity.

All rights reserved. No reuse allowed without permission.

Table 3. Work-related risk factors for TMA positivity and seropositivity among farmworkers, Monterey County, 2020.

\begin{tabular}{|c|c|c|c|c|c|}
\hline \multirow[t]{3}{*}{ Attribute } & \multirow[b]{2}{*}{$\begin{array}{l}\text { All enrolled } \\
\quad N=1107\end{array}$} & \multicolumn{2}{|c|}{$\begin{array}{c}\text { Current SARS-CoV-2 } \\
\text { infection (TMA) } \\
N=911\end{array}$} & \multicolumn{2}{|c|}{$\begin{array}{c}\text { Historical SARS-CoV-2 } \\
\text { infection (IgG reactivity) } \\
N=1058\end{array}$} \\
\hline & & $\begin{array}{c}\text { Positive } \\
N=118\end{array}$ & $\begin{array}{c}\text { Negative } \\
N=793\end{array}$ & $\begin{array}{c}\text { Positive } \\
N=201\end{array}$ & $\begin{array}{l}\text { Negative } \\
N=857\end{array}$ \\
\hline & $\begin{array}{l}n(\%) \text { or } \\
M \pm S D\end{array}$ & $\begin{array}{l}n(\%) \text { or } \\
M \pm S D\end{array}$ & $\begin{array}{l}n(\%) \text { or } \\
M \pm S D\end{array}$ & $\begin{array}{l}n(\%) \text { or } \\
M \pm S D\end{array}$ & $\begin{array}{l}n(\%) \text { or } \\
M \pm S D\end{array}$ \\
\hline \multicolumn{6}{|l|}{ H2A visa holder } \\
\hline No & $1029(93.0)$ & $107(12.7)$ & $733(87.3)$ & $188(19.2)$ & $792(80.8)$ \\
\hline Yes & $65(5.9)$ & $9(15.0)$ & $51(85.0)$ & $11(16.9)$ & $54(83.1)$ \\
\hline No answer & $13(1.2)$ & $2(18.2)$ & $9(81.8)$ & $2(15.4)$ & $11(84.6)$ \\
\hline \multicolumn{6}{|c|}{ Supervisor or mayordomo } \\
\hline No & 1015 (76.2) & $111(12.8)$ & $756(87.2)$ & $183(18.9)$ & $784(81.1)$ \\
\hline Yes & $50(4.5)$ & 7 (15.9) & $37(84.1)$ & $9(18.4)$ & $40(81.6)$ \\
\hline No answer & $42(3.8)$ & $0(0.0)$ & $0(0.0)$ & $9(21.4)$ & $33(78.6)$ \\
\hline \multicolumn{6}{|c|}{$\begin{array}{l}\text { Type of agricultural work } \\
\text { (ever/in the past } 2 \text { weeks) }^{\text {a }}\end{array}$} \\
\hline Worked in the fields & $825(74.5)$ & $100(14.7)^{*}$ & $580(85.3)$ & $162(20.4)^{*}$ & $633(79.6)$ \\
\hline Packing shed & $133(12.0)$ & $11(10.5)$ & $94(89.5)$ & $21(16.4)$ & $107(83.6)$ \\
\hline Processing facility & $63(5.7)$ & $4(7.0)^{\#^{\prime}}$ & $53(93.0)$ & $7(12.1)^{\#}$ & $51(87.9)$ \\
\hline Nursery & $38(3.4)$ & $4(12.1)$ & 29 (87.9) & $4(11.4)$ & $31(88.6)$ \\
\hline Truck driver & $38(3.4)$ & $4(12.1)$ & $29(87.9)$ & $3(9.1)^{\#}$ & $30(90.9)$ \\
\hline Packing truck & $22(2.0)$ & $1(4.8)$ & $20(95.2)$ & $2(9.5)$ & $19(90.5)$ \\
\hline Other & 21 (1.9) & $1(5.3)$ & $18(94.7)$ & $2(10.5)$ & 17 (89.5) \\
\hline No answer & $10(0.9)$ & $0(0.0)$ & $1(100.0)$ & $2(20.0)$ & $8(80.0)$ \\
\hline \multicolumn{6}{|l|}{ Worked indoors } \\
\hline No & 844 (76.2) & $98(14.3)^{\star}$ & $589(85.7)$ & $166(20.4)^{*}$ & $646(79.6)$ \\
\hline Yes & 262 (23.7) & $20(9.0)$ & $203(91.0)$ & $35(14.3)$ & $210(85.7)$ \\
\hline No answer & $1(0.1)$ & $0(0.0)$ & $1(100.0)$ & $0(0.0)$ & $1(100.0)$ \\
\hline \multicolumn{6}{|c|}{$\begin{array}{l}\text { Crops (ever/in the past } 2 \\
\text { weeks) }^{\mathrm{a}}\end{array}$} \\
\hline Berries & $236(28.6)$ & $14(7.2)^{*}$ & $181(92.8)$ & $39(16.7)^{\#}$ & $194(83.3)$ \\
\hline Leafy greens & $218(26.4)$ & $31(17.9)^{\#}$ & $142(82.1)$ & $50(24.2)^{\#}$ & $157(75.9)$ \\
\hline Broccoli & $155(18.8)$ & $28(18.9)^{\#}$ & $120(81.1)$ & $24(16.3)^{\#}$ & $123(83.7)$ \\
\hline Grapes & $59(7.2)$ & $10(21.3)^{\#}$ & $37(78.7)$ & $15(26.3)$ & $42(73.7)$ \\
\hline Peas & $52(6.3)$ & $16(30.8)^{*}$ & 36 (69.2) & $5(10.0)^{\dagger}$ & $45(90.0)$ \\
\hline Cauliflower & $42(5.1)$ & $5(13.5)$ & $32(86.5)$ & $11(30.6)^{\#}$ & $25(69.4)$ \\
\hline Celery & $19(2.3)$ & $2(11.8)$ & $15(88.2)$ & $3(18.8)$ & $13(81.3)$ \\
\hline Artichokes & $6(0.7)$ & $0(0.0)$ & $5(100.0)$ & $1(16.7)$ & $5(83.3)$ \\
\hline Other & $158(19.2)$ & $9(8.4)^{*}$ & $98(91.6)$ & $35(22.6)$ & $120(77.4)$ \\
\hline \multicolumn{6}{|c|}{$\begin{array}{l}\text { Commuted to work with non- } \\
\text { household members }\end{array}$} \\
\hline No & 707 (63.9) & $65(10.9)^{*}$ & $530(89.1)$ & $124(18.4)$ & $548(81.6)$ \\
\hline Yes & 380 (34.3) & $53(16.8)$ & 263 (83.2) & $72(19.7)$ & 294 (80.3) \\
\hline No answer & $20(1.8)$ & $0(0.0)$ & $0(0.0)$ & $5(25.0)$ & $15(75.0)$ \\
\hline \multicolumn{6}{|c|}{$\begin{array}{l}\text { Used face covering at work all } \\
\text { of the time }\end{array}$} \\
\hline No & $112(10.1)$ & $11(11.7)$ & $83(88.3)$ & 19 (18.1) & $86(81.9)$ \\
\hline Yes & 992 (89.6) & $107(13.1)$ & 709 (86.9) & $182(19.2)$ & $768(80.8)$ \\
\hline No answer & $3(0.3)$ & $0(0.0)$ & $1(100.0)$ & $0(0.0)$ & $3(100.0)$ \\
\hline \multicolumn{6}{|c|}{$\begin{array}{l}\text { Came within } 6 \text { feet from others } \\
\text { while working }\end{array}$} \\
\hline No & $501(45.3)$ & $52(12.6)$ & $361(87.4)$ & $95(19.7)$ & $388(80.3)$ \\
\hline Yes & $568(51.3)$ & 64 (13.4) & $413(86.6)$ & $97(18.0)$ & $441(82.0)$ \\
\hline
\end{tabular}


medRxiv preprint doi: https://doi.org/10.1101/2021.02.01.21250963; this version posted February 3, 2021. The copyright holder for this preprint (which was not certified by peer review) is the author/funder, who has granted medRxiv a license to display the preprint in perpetuity.

All rights reserved. No reuse allowed without permission.

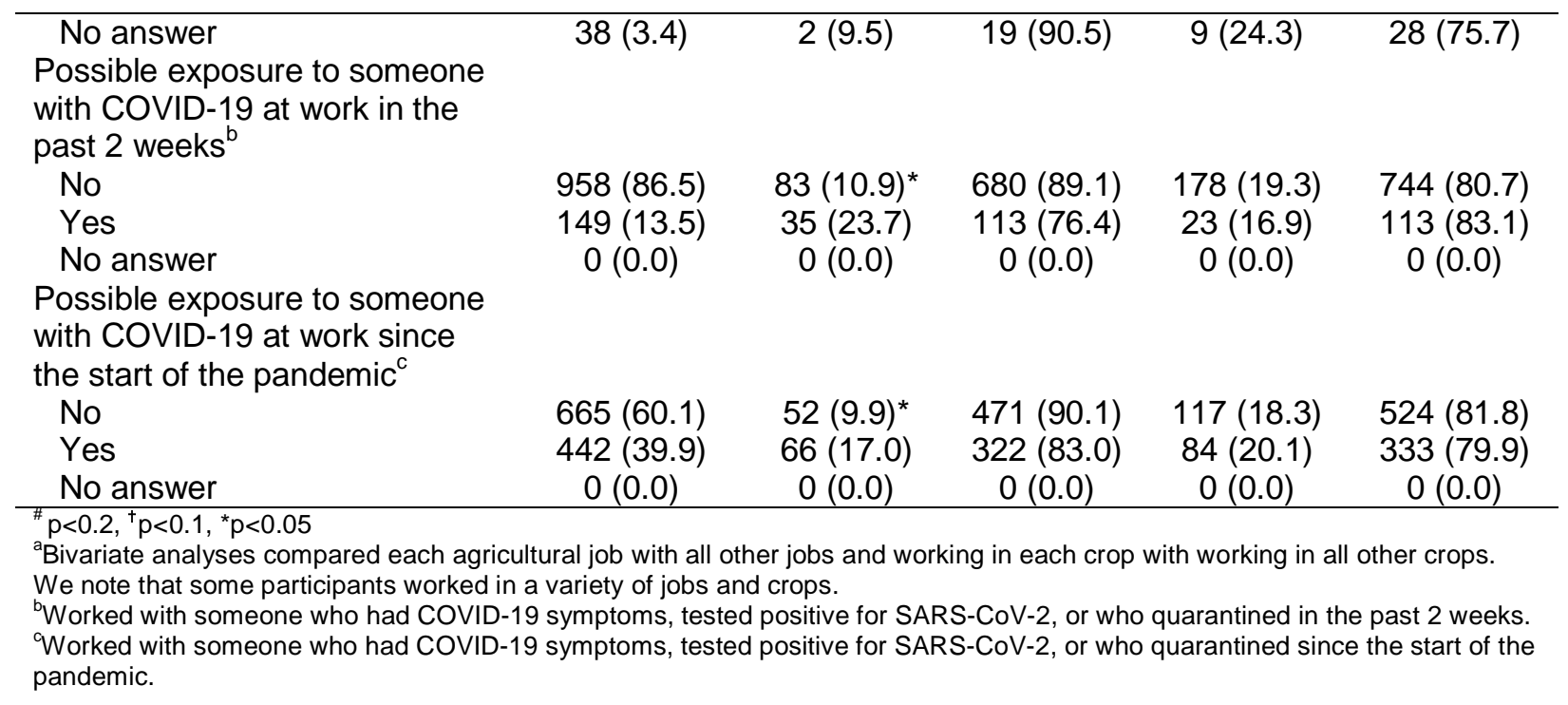


medRxiv preprint doi: https://doi.org/10.1101/2021.02.01.21250963; this version posted February 3, 2021. The copyright holder for this preprint (which was not certified by peer review) is the author/funder, who has granted medRxiv a license to display the preprint in perpetuity.

All rights reserved. No reuse allowed without permission.

Table 4. Employer-provided preventive measures and their association with TMA positivity and seropositivity among farmworkers, Monterey County, 2020.

\begin{tabular}{|c|c|c|c|c|c|}
\hline \multirow[t]{3}{*}{ Attribute } & \multirow[b]{2}{*}{$\begin{array}{c}\text { All enrolled } \\
\quad N=1107\end{array}$} & \multicolumn{2}{|c|}{$\begin{array}{c}\text { Current SARS-CoV-2 } \\
\text { infection (TMA) } \\
N=911\end{array}$} & \multicolumn{2}{|c|}{$\begin{array}{c}\text { Historical SARS-CoV-2 } \\
\text { infection (IgG } \\
\text { reactivity) } \\
N=1,058\end{array}$} \\
\hline & & $\begin{array}{c}\text { Positive } \\
N=118\end{array}$ & $\begin{array}{c}\text { Negative } \\
N=793\end{array}$ & $\begin{array}{c}\text { Positive } \\
N=201\end{array}$ & $\begin{array}{c}\text { Negative } \\
N=857\end{array}$ \\
\hline & $n(\%)$ & $n(\%)$ & $n(\%)$ & $n(\%)$ & $n(\%)$ \\
\hline \multicolumn{6}{|c|}{$\begin{array}{l}\text { Fever and symptoms } \\
\text { screening upon arrival at } \\
\text { workplace }\end{array}$} \\
\hline Neither & $495(44.7)$ & $54(16.6)^{*}$ & $272(83.4)$ & 92 (19.2) & $388(80.8)$ \\
\hline Either or both & $611(55.2)$ & $64(10.9)$ & $521(89.1)$ & $109(18.9)$ & $468(81.1)$ \\
\hline No answer & $1(0.1)$ & $0(0.0)$ & $0(0.0)$ & $0(0.0)$ & $1(100.0)$ \\
\hline \multicolumn{6}{|c|}{$\begin{array}{l}\text { Employer provided face } \\
\text { coverings }\end{array}$} \\
\hline No & 168 (15.2) & $15(12.1)$ & $109(87.9)$ & $26(16.1)$ & $136(84.0)$ \\
\hline Yes & 932 (84.2) & $102(13.0)$ & $681(87.0)$ & $174(19.6)$ & $715(80.4)$ \\
\hline No answer & $7(0.6)$ & $1(25.0)$ & $3(75.0)$ & $1(14.3)$ & $6(85.7)$ \\
\hline \multicolumn{6}{|c|}{ Employer provided gloves } \\
\hline No & $161(14.5)$ & $12(9.0)^{\#}$ & $121(91.0)$ & $26(17.1)$ & $126(82.9)$ \\
\hline Yes & $945(85.4)$ & $106(13.6)$ & $671(86.4)$ & $175(19.3)$ & $730(80.7)$ \\
\hline No answer & $1(0.1)$ & $0(0.0)$ & $1(100.0)$ & $0(0.0)$ & $1(100.0)$ \\
\hline \multicolumn{6}{|c|}{ Employer provided eye shields } \\
\hline No & $542(49.0)$ & $52(11.7)$ & $392(88.3)$ & $94(18.2)$ & $424(81.9)$ \\
\hline Yes & $564(51.0)$ & 66 (14.2) & $400(85.8)$ & $107(19.9)$ & $432(80.2)$ \\
\hline No answer & $1(0.1)$ & $0(0.0)$ & $1(100.0)$ & $0(0.0)$ & $1(100.0)$ \\
\hline \multicolumn{6}{|c|}{$\begin{array}{l}\text { Employer provided hand } \\
\text { washing stations }\end{array}$} \\
\hline No & $6(0.5)$ & $1(20.0)$ & $4(80.0)$ & $2(33.3)$ & $4(66.7)$ \\
\hline Yes & $1100(99.4)$ & $117(12.9)$ & $788(87.1)$ & $199(18.9)$ & $852(81.1)$ \\
\hline No answer & $1(0.1)$ & $0(0.0)$ & $1(100.0)$ & $0(0.0)$ & $1(100.0)$ \\
\hline \multicolumn{6}{|c|}{$\begin{array}{l}\text { Employer provided liquid soap } \\
\text { and paper towels }\end{array}$} \\
\hline No & $15(1.4)$ & $2(16.7)$ & $10(83.3)$ & $4(26.7)$ & $11(73.3)$ \\
\hline Yes & 1090 (98.5) & $116(12.9)$ & $781(87.1)$ & $196(18.8)$ & $845(81.2)$ \\
\hline No answer & $2(0.2)$ & $0(0.0)$ & $2(100.0)$ & $1(50.0)$ & $1(50.0)$ \\
\hline \multicolumn{6}{|c|}{$\begin{array}{l}\text { Employer provided hand } \\
\text { sanitizer }\end{array}$} \\
\hline No & $95(8.6)$ & $8(11.4)$ & $62(88.6)$ & $20(22.5)$ & 69 (77.5) \\
\hline Yes & $1011(91.3)$ & $110(13.1)$ & 730 (86.9) & $181(18.7)$ & 787 (81.3) \\
\hline No answer & $1(0.1)$ & $0(0.0)$ & $1(100.0)$ & $0(0.0)$ & $1(100.0)$ \\
\hline \multicolumn{6}{|c|}{$\begin{array}{l}\text { Workplace surfaces and tools } \\
\text { regularly disinfected and kept } \\
\text { clean }\end{array}$} \\
\hline No & $122(11.0)$ & $12(12.8)$ & $82(87.2)$ & $17(14.8)$ & 98 (85.2) \\
\hline Yes & $946(85.5)$ & 98 (12.5) & $687(87.5)$ & 175 (19.3) & $730(80.7)$ \\
\hline No answer & 39 (3.5) & $8(25.0)$ & $24(75.0)$ & $9(23.7)$ & $29(76.3)$ \\
\hline \multicolumn{6}{|c|}{$\begin{array}{l}\text { Employer staggered breaks to } \\
\text { reduce exposure }\end{array}$} \\
\hline No & 608 (54.9) & 66 (13.4) & $428(86.6)$ & 112 (19.2) & $471(80.8)$ \\
\hline Yes & $492(44.4)$ & 51 (12.4) & $362(87.7)$ & $89(19.0)$ & $380(81.0)$ \\
\hline No answer & $7(0.6)$ & $1(25.0)$ & $3(75.0)$ & $0(0.0)$ & $6(100.0)$ \\
\hline Employer provic & & & & & \\
\hline
\end{tabular}


medRxiv preprint doi: https://doi.org/10.1101/2021.02.01.21250963; this version posted February 3, 2021. The copyright holder for this preprint (which was not certified by peer review) is the author/funder, who has granted medRxiv a license to display the preprint in perpetuity.

All rights reserved. No reuse allowed without permission.

\begin{tabular}{|c|c|c|c|c|c|}
\hline \multicolumn{6}{|c|}{ on COVID-19 symptoms } \\
\hline No & $64(5.8)$ & $6(15.0)$ & $34(85.0)$ & $17(27.4)^{+}$ & $45(72.6)$ \\
\hline Yes & 1040 (94.0) & $112(12.9)$ & 758 (87.1) & $184(18.5)$ & $809(81.5)$ \\
\hline No answer & $3(0.3)$ & $0(0.0)$ & $1(100.0)$ & $0(0.0)$ & $3(100.0)$ \\
\hline \multicolumn{6}{|c|}{$\begin{array}{l}\text { Employer provided information } \\
\text { on how to protect themselves } \\
\text { at work }\end{array}$} \\
\hline No & $37(3.3)$ & $1(4.8)$ & $20(95.2)$ & $12(34.3)^{*}$ & $23(65.7)$ \\
\hline Yes & $1067(96.4)$ & $117(13.2)$ & $772(86.8)$ & $189(18.5)$ & $831(81.5)$ \\
\hline No answer & $3(0.3)$ & $0(0.0)$ & $1(100.0)$ & $0(0.0)$ & $3(100.0)$ \\
\hline \multicolumn{6}{|c|}{$\begin{array}{l}\text { Employer provided information } \\
\text { on how to protect themselves } \\
\text { at home and in the community }\end{array}$} \\
\hline No & $70(6.3)$ & $3(6.4)^{\#}$ & $44(93.6)$ & $17(25.4)^{\#}$ & $50(74.6)$ \\
\hline Yes & $1034(93.4)$ & 115 (13.3) & $748(86.7)$ & $184(18.6)$ & $804(81.4)$ \\
\hline No answer & $3(0.3)$ & $0(0.0)$ & $1(100.0)$ & $0(0.0)$ & $3(100.0)$ \\
\hline \multicolumn{6}{|c|}{$\begin{array}{l}\text { Employer provided information } \\
\text { on whom to call if they were } \\
\text { sick }\end{array}$} \\
\hline No & $134(12.1)$ & $18(18.2)^{\#}$ & $81(81.8)$ & $27(20.9)$ & $102(79.1)$ \\
\hline Yes & $970(87.6)$ & $100(12.3)$ & $711(87.7)$ & $174(18.8)$ & $752(81.2)$ \\
\hline No answer & $3(0.3)$ & $0(0.0)$ & $1(100.0)$ & $0(0.0)$ & $3(100.0)$ \\
\hline \multicolumn{6}{|c|}{$\begin{array}{l}\text { Employer provided information } \\
\text { on their ability to get free } \\
\text { testing and treatment if they } \\
\text { were sick }\end{array}$} \\
\hline No & $303(27.4)$ & $31(13.1)$ & $206(86.9)$ & $62(21.5)$ & $227(78.6)$ \\
\hline Yes & $800(72.3)$ & 87 (13.0) & $585(87.1)$ & $138(18.0)$ & $627(82.0)$ \\
\hline No answer & $4(0.4)$ & $0(0.0)$ & $2(100.0)$ & $1(25.0)$ & $3(75.0)$ \\
\hline \multicolumn{6}{|c|}{$\begin{array}{l}\text { Employer provided information } \\
\text { on where to get housing if they } \\
\text { needed to quarantine or } \\
\text { isolate away from home }\end{array}$} \\
\hline No & $607(54.8)$ & $70(14.1)$ & $428(85.9)$ & $112(19.3)$ & $467(80.7)$ \\
\hline Yes & $496(44.8)$ & $48(11.7)$ & 363 (88.3) & $88(18.5)$ & $387(81.5)$ \\
\hline No answer & $4(0.4)$ & $0(0.0)$ & $2(100.0)$ & $1(25.0)$ & $3(75.0)$ \\
\hline \multicolumn{6}{|c|}{$\begin{array}{l}\text { Employer provided information } \\
\text { on the importance of staying } \\
\text { away from work if they were } \\
\text { sick }\end{array}$} \\
\hline No & $78(7.1)$ & $5(9.1)$ & 50 (90.9) & $15(19.5)$ & $62(80.5)$ \\
\hline Yes & $1024(92.5)$ & $113(13.2)$ & 741 (86.8) & $185(19.0)$ & $791(81.1)$ \\
\hline No answer & $5(0.5)$ & $0(0.0)$ & $2(100.0)$ & $1(20.0)$ & $4(80.0)$ \\
\hline \multicolumn{6}{|c|}{$\begin{array}{l}\text { Employer provided information } \\
\text { on their benefit to get paid to } \\
\text { stay away from work if they } \\
\text { were sick }\end{array}$} \\
\hline No & $334(30.2)$ & $36(13.7)$ & 227 (86.3) & 58 (18.4) & $258(81.7)$ \\
\hline Yes & 769 (69.5) & $82(12.7)$ & 564 (87.3) & $142(19.2)$ & $596(80.8)$ \\
\hline No answer & $4(0.4)$ & $0(0.0)$ & $2(100.0)$ & $1(25.0)$ & $3(75.0)$ \\
\hline \multicolumn{6}{|c|}{$\begin{array}{l}\text { Received education about } \\
\text { COVID-19 from medical staff } \\
\text { at workplace }\end{array}$} \\
\hline No & $714(64.5)$ & $76(13.0)$ & $508(87.0)$ & $126(18.5)$ & $556(81.5)$ \\
\hline Yes & $373(33.7)$ & $41(13.1)$ & 271 (86.9) & $73(20.5)$ & $283(79.5)$ \\
\hline No answer & $20(1.8)$ & $1(6.7)$ & $14(93.3)$ & $2(10.0)$ & $18(90.0)$ \\
\hline
\end{tabular}


medRxiv preprint doi: https://doi.org/10.1101/2021.02.01.21250963; this version posted February 3, 2021. The copyright holder for this preprint (which was not certified by peer review) is the author/funder, who has granted medRxiv a license to display the preprint in perpetuity.

All rights reserved. No reuse allowed without permission.

\footnotetext{
${ }^{\#} p<0.2,{ }^{\dagger} p<0.1,{ }^{*} p<0.05$
} 
medRxiv preprint doi: https://doi.org/10.1101/2021.02.01.21250963; this version posted February 3, 2021. The copyright holder for this preprint (which was not certified by peer review) is the author/funder, who has granted medRxiv a license to display the preprint in perpetuity.

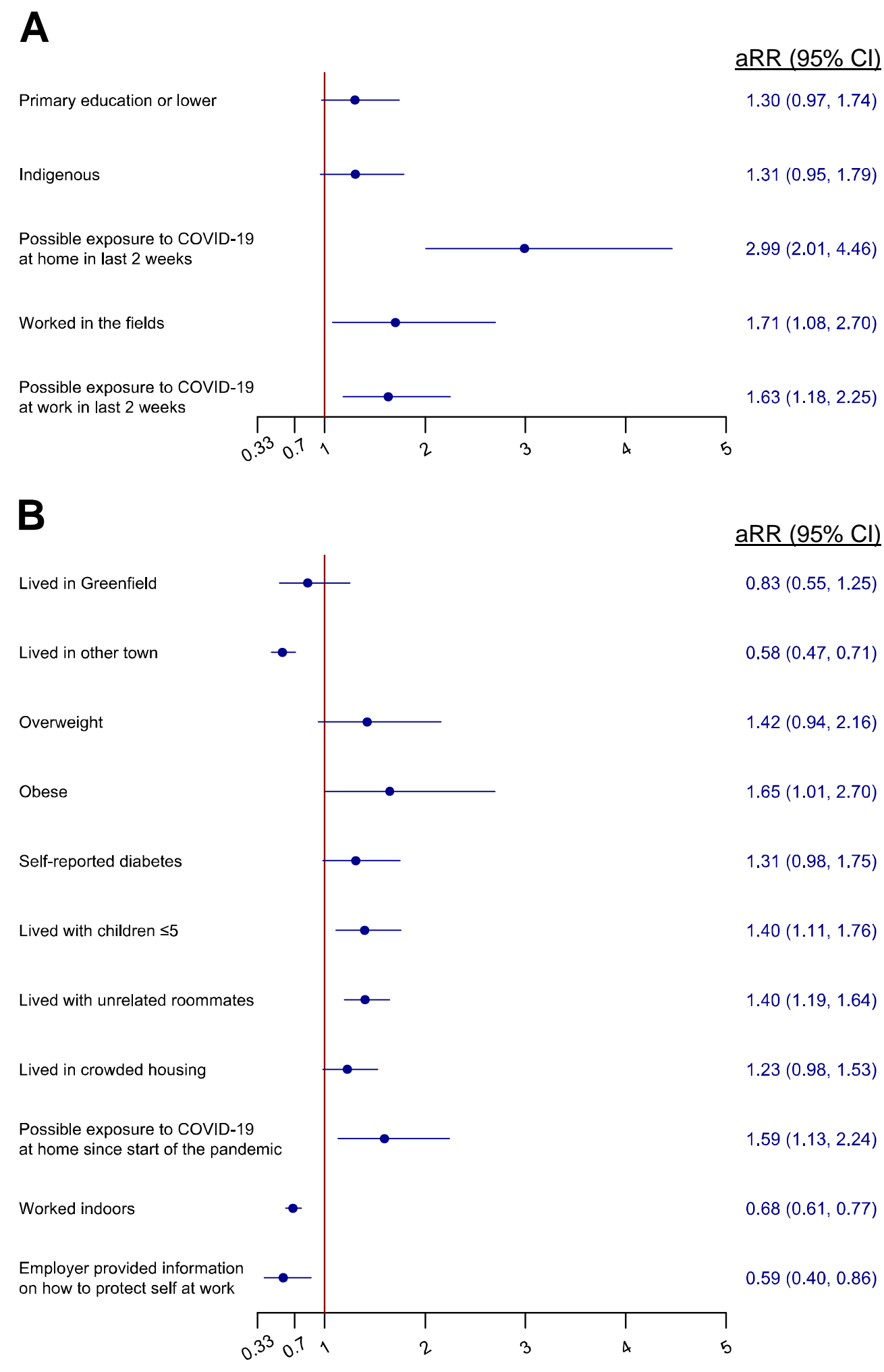

Figure 1. Change in: (A) TMA-positivity risk for explanatory variables among current farmworkers $(\mathrm{n}=911)$, and $(\mathbf{B})$ seropositivity risk for explanatory variables among all farmworkers who provided a blood sample $(n=1,058)$. Adjusted relative risks $(a R R)$ and $95 \%$ confidence intervals from conditional fixedeffects Poisson models. 